\title{
Preferences in Local Taxes in Poland
}

\section{Lukasz FURMAN}

State Higher Vocational School Stanisława Pigoń, Krosno, Poland; lukasz.furman@pwsz.krosno.pl

\begin{abstract}
The article is devoted to tax preferences applicable to local taxes in Poland. The scope of local taxes includes, in particular, property tax and vehicle tax. They result from one legal act and are paid into the municipal budget. Other taxes that flow into the same budget (but follow from other laws) are: agricultural tax and forestry tax. These taxes are undoubtedly of a local nature as they contribute to the budgets of local government units. The article focuses on the tax preferences resulting from these taxes. The main issue discussed was the issue of shaping tax rates and their reductions, introduction of exemptions from the collection of local taxes. Data for the research were obtained from reports on the execution of budgets of local government units. The research shows that real estate tax has the greatest fiscal significance and its construction has the most solutions related to tax preferences related to the tax rate and exemptions. It was subsequently pointed out that a tax on means of transport is an important tax from the point of view of tax concessions reducing the tax burden.
\end{abstract}

Keywords: local taxes; vehicle tax; property tax; forest tax; agricultural tax

JEL Classification: H2; H7; E6

\section{Introduction}

Local taxes are an important source of income for municipalities, which must pursue important public objectives at local level. Sometimes municipalities decide to introduce solutions to the construction of local taxes, which will also be aimed at achieving important economic goals. Such a solution may be various types of tax preferences, related to e.g.: reduction of the tax rate, exemption from tax of certain groups of taxpayers. Specific solutions are to exert desired changes in the local economy characterized by increased economic activity. This will translate into greater economic development of the region in the future. This article focuses on presenting the subject of local taxes in Poland and indicating the preferences we deal with in the practical implementation of tax obligations. They are different in nature as they can affect different types of taxable persons. In connection with the subject matter pursued, a hypothesis was put forward that the largest share of tax preferences to taxes collected occurs in the real estate tax, and then in the tax on means of transport, and they mainly determine the nature of the tax policy. In other taxes, i.e. tax preferences are of little importance. In order to verify the scientific hypothesis, the current literature on the subject referring to tax preferences and statistical data related to the applied tax reductions was reviewed. On this basis, the conclusions of the study were finally clarified.

\section{The System of Local Taxes in Poland}

In Poland, the system of local taxes that contribute to the budget of communes includes: (a) real estate tax, (b) tax on means of transport, (c) the agricultural tax, and (d) forestry tax.

Real estate tax on buildings or parts of buildings, structures or parts thereof intended for nonagricultural or forestry economic activities, or on land covered by these provisions. The basis for the property tax assessment is the usable floor area of buildings or parts thereof multiplied by the appropriate tax rate established by the municipal council. In case of structures, the tax is calculated as a product of $2 \%$ of the value of structures determined for depreciation purposes as at 1 January of the tax year or, in special cases, their market value. The amount of taxation in relation to land is the product of its area and the specific tax rate. The upper limits of the rates are set annually by the Minister of Finance, but municipalities have the possibility to reduce them. Some municipalities do not change the 
statutory rates, which is undoubtedly not attractive for taxpayers because they cannot count on a tax reduction. The property tax liability in the real estate tax is imposed on natural persons, legal entities and organizational units without legal personality which are its owners, holders or managers. Real estate tax is the most efficient local tax, which is the reason why budgets receive the most money from this tax.

Tax on means of transport, applicable to lorries, trailers, semi-trailers, buses. The tax is paid by the owners of the means of transport. The Council of each municipality shall determine in a resolution the amount of the tax on means of transport, bearing in mind the principle that it may not exceed the limit specified in the Act. When setting the rates, the municipal council should take into account the type of measure, the cylinder capacity or engine power, the payload, the total weight and may also take into account the age or value of the means of transport.

The agricultural tax is paid by the owners of land belonging to the agricultural holding with a total area exceeding $1 \mathrm{ha}$. Land belonging to or owned or held by a natural or legal person is subject to agricultural tax. Land under lakes and flowing waters, constituting wastelands, entered in the property of historic monuments, occupied for economic activity other than agricultural activity, is excluded from taxation. The agricultural tax is the number of conversion hectares, which is determined on the basis of the area, types and classes of agricultural land resulting from the land register and inclusion in the tax district. The legislator established four tax districts, which include communes and towns, depending on economic, production and climatic conditions. The table contained in the Agricultural Tax Act specifies the conversion rates according to which the agricultural area expressed in hectares (physical hectares) is converted into conversion hectares. In order to calculate the tax, the relevant specific rate for 1 conversion hectare must be applied. Agricultural tax rates are annual specific rates determined by dividing 1 conversion hectare by the price of 2.5 quintals of rye calculated according to the average purchase price of rye for the first 3 quarters of the year preceding the tax year.

Conversion of agricultural tax rates, which take into account the above mentioned criteria, is presented in the table 1 below.

Table 1. Scale of agricultural tax.

\begin{tabular}{ccccccccc}
\hline $\begin{array}{c}\text { Types of agricultural } \\
\text { area }\end{array}$ & \multicolumn{3}{c}{ Arable land } & \multicolumn{5}{c}{ Meadows and pastures } \\
\hline $\begin{array}{c}\text { Tax districts } \\
\text { Class of agricultural area }\end{array}$ & I & II & III & IV & I & II & III & IV \\
\hline I & 1.95 & 1.80 & 1.65 & 1.45 & 1.75 & 1.60 & 1.45 & 1.35 \\
\hline II & 1.80 & 1.65 & 1.50 & 1.35 & 1.45 & 1.35 & 1.25 & 1.10 \\
\hline III a & 1.65 & 1.50 & 1.40 & 1.25 & & & & \\
\hline III & & & & & 1.25 & 1.15 & 1.05 & 0.95 \\
\hline III b & 1.35 & 1.25 & 1.15 & 1.00 & & & & \\
\hline IV a & 1.10 & 1.00 & 0.90 & 0.80 & & & & \\
\hline IV & & & & & 0.75 & 0.70 & 0.60 & 0.55 \\
\hline IV b & 0.80 & 0.75 & 0.65 & 0.60 & & & & \\
\hline V & 0.35 & 0.30 & 0.25 & 0.20 & 0.20 & 0.20 & 0.15 & 0.15 \\
\hline VI & 0.20 & 0.15 & 0.10 & 0.05 & 0.15 & 0.15 & 0.10 & 0.05 \\
\hline
\end{tabular}

Source: Agricultural Tax Act.

Forestry tax - all forests are subject to forestry tax except forests not related to forest management, occupied by recreational centers, building and recreation plots and excluded by administrative decisions from forest management for purposes other than forestry. Forests not subject to forest tax are subject to property tax. The tax obligation with respect to forestry tax is imposed on natural persons, legal persons, and organizational units without legal personality, which are the owners. Forests with stands up to 40 years old, forests included in nature reserves and national parks, protective forests and forests entered in the register of monuments are obligatorily exempt from taxation. The structure of the tax base is complex. These are the number of conversion hectares 
determined on the basis of the area of the main tree species in the stand and the grading classes. The table contained in the Forest Act contains forest area conversion factors expressed in physical hectares per conversion hectare, taking into account tree species in stands and stand classification. The forest tax from 1 conversion ha for the tax year amounts to the monetary equivalent of $0.200 \mathrm{~m} 3$ of coniferous sawmill wood, calculated according to the average sales price of wood obtained by the forest inspectorates for the first three quarters of the year preceding the tax year. The average selling price of coniferous sawn timber is determined on the basis of the announcement of the President of the Central Statistical Office, which is announced within 20 days after the end of the third quarter. For protective forests, forests belonging to nature reserves and national parks, and forests for which no forest management plan or simplified forest management plan has been drawn up, the forest tax for the fiscal year is the monetary equivalent of 0.3 q rye per 1 ha of physical forest and forest land, determined on the basis of the land register.

The taxes presented above are the main tax revenues of the municipalities'; budgets. Their fiscal performance varies. The highest income usually comes from property tax, which is due to a very large tax base. The lowest tax revenue comes from the forest tax, which is due to the small number of forests. The presented taxes are subject to various tax exemptions and discounts, which will be presented in the next part of the article.

\section{The Concept and Scope of Tax Preferences}

Tax preferences are a kind of tax advantage that is provided for in the tax laws of a country. For taxpayers, they are certain solutions that allow to reduce the tax burden or shift the tax assessment and collection to a period convenient for the taxpayer (Tegler 1998).

The notion of tax preferences refers to all legally binding elements allowing to reduce the tax burden. Such solutions do not have to be targeted at all taxpayers. They can only be used by a narrow group of taxpayers. A state with unlimited tax authority may introduce various types of tax solutions only to a specific group of entities, e. g. a company with unlimited tax authority. In order to develop a particular industry. Offering tax reductions by the state can even be treated as a kind of subsidy to the taxpayer (Tipke 1998). These tax preferences are part of the applicable tax policy. As a tool for economic impact, they refer to the impact on social and social objectives. If taxpayers use solutions to help them reduce their taxes, they can become more loyal to the state (Lamberton, De Neve, and Norton 2014).

According to the norms of the OECD organization, a tax preference is a transfer of public funds made as a result of a reduction in tax liability in relation to the adopted tax standard (OECD). The tax arrangements in place that result in a tax reduction are undoubtedly a tax preference. Among them we can observe: tax reliefs and deductions and tax exemptions. Relief and deduction allows you to reduce the tribute in a certain proportion. The tax exemption, on the other hand, refers to the exclusion of given tax sources or entities from taxation. In the Polish Act of 1997, the Tax Ordinance, which constitutes the backbone of the tax system, stipulates that: tax relief is understood as exemptions, deductions, reductions or reductions provided for in the tax law, the application of which results in a reduction of the tax base or the amount of tax with the exception of a reduction of the amount of output tax by the amount of input tax, within the meaning of the VAT regulations, and other deductions constituting an element of the tax structure (the Tax Ordinance).

The above-mentioned definitions (OECD and Tax Ordinance) correspond to each other, however, the former is much broader than the Polish statutory definition. As it was rightly noted in Report No. 7 on Tax Preferences in Poland prepared by the Ministry of Finance in Poland in 2016 that tax preferences are an alternative to direct budget transfers. The difference is, in fact, that spending money from the state budget involves two stages: receiving money and spending it - in the case of tax preferences, the revenue is immediately consumed. The Polish economic reality shows that tax preferences are most noticeable in direct taxes, e. g. income taxes. They play a lesser role in indirect taxes. Polish tax services are trying to monitor the situation with regard to tax preferences by calculating the amount of revenue foregone in the budget. 
Table 2. Tax preferences in Poland in the years 2009-2015 - PLN.

\begin{tabular}{lccccccc}
\hline & $\mathbf{2 0 0 9}$ & $\mathbf{2 0 1 0}$ & $\mathbf{2 0 1 1}$ & $\mathbf{2 0 1 2}$ & $\mathbf{2 0 1 3}$ & $\mathbf{2 0 1 4}$ & $\mathbf{2 0 1 5}$ \\
\hline $\begin{array}{l}\text { Value of } \\
\begin{array}{l}\text { Preferences } \\
\text { in mln }\end{array}\end{array}$ & 59.517 & 67.241 & 72.041 & 73.795 & 76.945 & 79.777 & 82.710 \\
\hline $\begin{array}{l}\text { Preferences } \\
\text { \% GDP }\end{array}$ & 4.43 & 4.75 & 4.72 & 4.63 & 4.70 & 4.61 & 4.60 \\
\hline
\end{tabular}

Source: Report no 7 Preferencje podatkowe $w$ Polsce $w$ latach 2009-2015, Ministry of Finance 2018 r. https://www.podatki.gov.pl/media/1221/preferencje-podatkowe-w-polsce-nr-7.pdf

The table below shows that the value of tax preferences in Poland in the years 2009-2015 was steadily increasing. Within seven years it has increased by over 20 billion PLN. The value of the applied preferences in relation to GDP did not show a high fluctuation. In the last two years under review, it has been almost unchanged and stands at around $4.6 \%$ of GDP.

\section{Tax Preferences in Local Taxes}

Exemptions from the real estate tax for the benefit of local taxpayers are at the forefront of the statutory regulations on local taxes:

- real estate or parts thereof occupied for the needs of local government authorities and administration,

- on condition of reciprocity - real estate owned by foreign countries or international organizations or transferred to them for perpetual usufruct, intended for the seats of diplomatic representations, consular posts and other missions enjoying privileges and immunities in accordance with international laws, agreements or customs,

- public road structures and land occupied by public roads, including road lanes,

$\circ$ buildings used exclusively for public rail transport and land occupied by them,

- port infrastructure structures, infrastructure structures providing access to, and land occupied by, ports and marinas,

- land under running water and navigable canals, with the exception of lakes and land occupied by reservoirs or hydroelectric power stations,

- farm buildings or parts of farm buildings connected with forestry activities, occupied by special sections of agricultural production and agricultural holdings within the meaning of the provisions on agricultural tax, farm buildings or parts of farm buildings connected with agricultural activities,

- real estate or parts thereof occupied for the needs of statutory activity of the associations among children and youth in the field of education, upbringing, science and technology, physical culture and sport, with the exception of those used for business activity, and land permanently occupied for camps and holiday bases for children and youth,

- buildings and land entered individually in the register of monuments, provided that they are maintained and maintained in accordance with the provisions on the protection of monuments, with the exception of parts occupied for economic activities,

- buildings and land owned by registered museums,

- real estate or parts thereof exempt from real estate tax pursuant to separate acts, buildings and structures newly built or modernised, put into use, used by the group for its statutory activity, after obtaining an entry of the group in the register of groups - within 5 years from the date of obtaining an entry of the group in the register.

Other exemptions may be decided by the commune within the framework of a resolution. A very common solution applied by communes is exemption from real estate tax for entrepreneurs who conduct their business activity within special economic zones. Currently, 14 zones operate in Poland, offering various solutions. Among the exemptions from real estate tax there are also author's solutions in communes directed only and exclusively for a specific type of entrepreneurs. An example is the 
commune of Radymno in the south of Poland, which offers a property tax exemption for business entities, but only after a strictly specified investment (real estate construction) has been completed in the commune. The entrepreneur must therefore submit an appropriate application in order to obtain the exemption. The length of the period during which the entrepreneur does not pay the means of transport tax is: (a) one year, if the value of the new investment is at least PLN 100,000; (b) two years, if the value of the new investment is at least PLN 300,000; (c) three years, if the value of the new investment is at least PLN 500,000 and the tax-exempt entity will conduct business activity for a period of 6 years under pain of losing the right to exemption for the entire period during which it benefited from the exemption.

In turn, the City of Wrocław and the Municipality of Wrocław provided for an exemption from property tax. The rules of the exemptions stipulate that for every created workplace connected with a new investment in Wrocław, a property tax exemption is granted for $60 \mathrm{~m} 2$ of buildings or parts of buildings occupied for business activity. The exemption period is 12 months if up to two jobs are created. The exemption can be extended by 6 months if another job is created. Taxpayers are obliged to maintain newly created jobs in Wrocław, at least 3 years from the date of filling the first position (small and medium enterprises), and 5 years in the case of large enterprises. With regard to property tax and vehicle tax, municipalities mostly adopt specific tax rates that are lower than the upper limit set in the Act. This can also be considered as some kind of tax relief related to the reduction of tax liability.

As regards the tax on means of transport, the law regulating the tax provides for an exemption from the payment of this tax for the means of transport:

- means of transport (subject to reciprocity) owned by diplomatic representations, consular posts and other foreign missions, enjoying privileges and immunities pursuant to international laws, agreements or customs, and members of their staff, as well as other persons equal to them, if they are not Polish citizens and do not have a permanent residence in the territory of the Republic of Poland;

- means of transport constituting mobilization reserves, special vehicles and vehicles used for special purposes within the meaning of the road traffic regulations;

$\circ$ historic vehicles, within the meaning of road traffic regulations.

Exemptions are also provided for in the agricultural tax for:

- the agricultural area of class V, VI and VIz and the wooded and shrubby areas established on the agricultural area, (b) farmland resulting from the use of uncultivated land - for a period of 5 years, counting from the year following the end of the use of the land;

- land occupied by water reservoirs used for supplying water to the population;

- land under flood embankments and land located in embankments;

- higher education institutions, public and non-public organizational units covered by the education system and the bodies running them, within the scope of land occupied for educational activity;

- entrepreneurs with the status of a research and development centre obtained on the basis of the principles specified in the provisions on certain forms of supporting innovative activity in relation to the objects of taxation seized for the purposes of conducted research and development works. Agricultural taxpayers are also granted investment relief, which is subject to deduction of $25 \%$ of investment expenditure from the agricultural tax due on land located in the commune in which the investment was made. Investment relief is granted in connection with expenses incurred for the construction and modernization of livestock buildings used for breeding and maintenance of farm animals and environmental protection facilities.

The latest forestry tax provides for exemptions from the payment of this tax in the following cases: woods with stands up to 40 years old; forests entered individually into the register of monuments; and organic land. 
The economic literature shows that municipalities applying tax preferences make the most of tax rate reductions. The authors of the studies by Galiński, Felis, Wołowiec, Skica, Kiebała, Świaniewicz also point to the second solution in the field of tax preferences, i. e. the tax preference of the Republic of Poland (Galiński 2016; Felis 2017; Świaniewicz 2016; Wołowiec, Skica, and Kiebała 2011).

Table 3. The effects of reliefs and exemptions in taxes granted by the municipalities in 2016 in thousand PLN.

\begin{tabular}{|c|c|c|c|c|}
\hline Specification & $\begin{array}{c}\text { Tax } \\
\text { revenue }\end{array}$ & $\begin{array}{c}\text { Reduction of upper } \\
\text { tax rates }\end{array}$ & $\begin{array}{l}\text { Reliefs and } \\
\text { exemption }\end{array}$ & $\begin{array}{c}\text { Indicator in \% } \\
\qquad(3+4): 2\end{array}$ \\
\hline 1 & 2 & 3 & 4 & 5 \\
\hline \multicolumn{5}{|c|}{ Agricultural tax } \\
\hline 2016 & 1513458 & 138032 & 1335 & $9.21 \%$ \\
\hline 2017 & 1463712 & 115467 & 1340 & $7.98 \%$ \\
\hline 2018 & 1460549 & 110443 & 1192 & $7.64 \%$ \\
\hline \multicolumn{5}{|l|}{ Property tax } \\
\hline 2016 & 20774468 & 2095574 & 711844 & $13.51 \%$ \\
\hline 2017 & 13372486 & 1811822 & 598058 & $18.02 \%$ \\
\hline 2018 & 13800359 & 1962369 & 611119 & $18.65 \%$ \\
\hline \multicolumn{5}{|l|}{ Forest tax } \\
\hline 2016 & 295943 & 2141 & 502 & $0.89 \%$ \\
\hline 2017 & 290433 & 1453 & 563 & $0.69 \%$ \\
\hline 2018 & 299590 & 1527 & 529 & $0.69 \%$ \\
\hline \multicolumn{5}{|l|}{ Vehicle tax } \\
\hline 2016 & 1055224 & 763031 & 3893 & $72.68 \%$ \\
\hline 2017 & 752497 & 587367 & 6645 & $78.94 \%$ \\
\hline 2018 & 785621 & 701849 & 2074 & $89.60 \%$ \\
\hline
\end{tabular}

Source: Information on the execution of budgets of local government units for 2016-2018, www.mf.gov.pl

The data presented in Table 3 show that the highest revenues of the commune in 2016-2018 were obtained from property tax, agricultural tax, and then from the tax on means of transport and forestry tax. The greatest tax preferences in all taxes resulted from the reduction of the upper tax rates that were provided for in the relevant legal acts. Reliefs and exemptions from these taxes played a much smaller role. In the course of the study, the value of the allowances and exemptions granted, the amount of taxes resulting from the reduction of the upper tax rates by the municipal councils were compared with the sum of tax revenues from each tax. The calculation of the indicator shows that the highest level of tax preference was given to the vehicle tax, as it ranged from $72.68 \%$ (2016) to $89.60 \%$ (2018) during the period considered.

The second place according to the calculated index was taken by the real estate tax. The preferences applied reached $13.51 \%$ (2016) of the receipts during the period considered up to $18.65 \%$ (2018). It follows from the above that municipal councils with the possibility to reduce tax rates were much more willing to do so in the area of tax on means of transport than in the area of property tax. There are known in Poland communes, which even encouraged to conduct business activity and establish a company's seat on their territory. The most frequent incentives were exemptions from the obligation to pay tax on means of transport.

The last of the analyzed tributes, i.e. agricultural and forestry taxes had the lowest tax preferences in 2016-2018. In the case of the agricultural tax, they stood at 7.64\% (2018) and 9.21\% (2016) of the receipts recorded. Since the beginning of 2016, the value of the applied tax preferences has been gradually decreasing. As far as forestry tax is concerned, the value of the preferences during the period considered never exceeded $1 \%$ of the income from forestry tax.

After the verification of statistical data, we can state that the municipalities applied tax policy aimed at the application of tax preferences, which was most visible in the tax on means of transport and in the tax on real estate. It had a much smaller impact on agricultural tax and forestry tax. 


\section{Conclusions}

The presented topic of tax preferences in local taxes in Poland is undoubtedly important from the point of view of local economy observed in the communes. Tax solutions aimed at reducing the tax burden contribute to local economic development. The hypothesis put forward at the beginning has not been confirmed. The verification of the statistical data established that the greatest tax preferences with regard to tax revenue are in the tax on means of transport and then in the tax on real estate. It follows from the above that local authorities attach great importance to the existence of tools to reduce taxes due. Although the hypothesis was verified negatively, the established state of functioning of tax preferences in local taxes is favorable for the development of community in Poland.

\section{References}

Felis Paweł, and Rosłaniec Henryk. 2017. The Application of Tax on Means of Transport in Local Tax Policy in Poland. Evidence of City Counties. Journal of Management and Financial Sciences: 28, 9-30.

Galiński Paweł. 2016. Znaczenie preferencji podatkowych w podatku od nieruchomości dla budżetów jednostek samorządu terytorialnego. Podatki i Opłaty Lokalne: 11, p. 40.

Lamberton Cait, De Neve Jan Emmanuel, and Norton Michael. 2014. Eliciting Taxpayer Preferences Increases Tax Compliance. Available online: https://papers.ssrn.com/sol3/papers.cfm?abstract_id=2365751 (accessed on 10 January 2020).

Tegler Eugeniusz. 1998. Preferencje podatkowe (wybrane aspekty teoretyczne i prawne), Roczniki Nauk Prawnych, Tom VIII, pp. 149-161.

Tipke Kraus. 1985. Steuerrecht. Ein systematischer Grundriss. Köln, p 136.

Traxel Wolfgang. 1986. Die Freibeträge des Einkommensteuergesetzes. Eine systematische Untersuchung unter Gerechtigkeitsaspekten. Frankfurt am Main-Bern-NewYork, p. 9.

Skica Tomasz, Kiebała Andrzej, and Wołowiec Tomasz. 2011. Czy redukcja stawek w podatku od środków transportowych realizuje stymulacyjną funkcje opodatkowania? Samorzad Terytorialny: 7-8, 152-164.

Swianiewicz Paweł, and Łukomska Julita. 2016. Local Tax Competition in Poland? Miscellanea Geographica Regional Studies on Development: 3, 37-43.

Wołowiec Tomasz. 2012. Preferencje $\mathrm{w}$ podatku od środków transportu a decyzje gospodarcze firm transportowych (badania własne. Finanse Komunalne: 7-8, 61-72. 